\title{
Äänilevy ja lähdekritiikki
}

Äänitteet ja erityisesti kaupalliset äänilevyt sisältävät usein musiikin historian tutkimuksen kannalta erittäin lupaavaa materiaalia. Englannin kielen sana 'record' merkitsee sattuvasti paitsi 'äänilevyä' ja 'nauhoitetta', myös 'muistiinpanoa' ja 'todistuskappaletta'. Monikossa sana merkitsee vielä 'asia- ja aikakirjoja' sekä 'arkistoa'. Äänilevyt ovat tosiaankin muistiinpanoja menneisyydestä (vrt. Conte 1995), ja niitä voi käyttää todistuskappaleina tutkimuksessa. Äänitteiden erikoisluonne lähderyhmänä aiheuttaa kuitenkin ongelmia, joita voi ratkoa soveltamalla historiatieteen tutkimusmetodeja. Tässä artikkelissa tarkastelen muita kuin tutkimustarkoituksiin tehtyjä äänitteitä.

Monet seikat rajoittavat äänilevyjen lähdekäyttöä. Vaikka diskografisen tutkimuksen juuret juontuvat jo 1930-luvulle, kattavat diskografiat ovat harvinaisia (ks. Gronow 1991, 234-235). Lisäksi musiikintutkijat eivät ole olleet erityisen kiinnostuneita pohtimaan historiantutkimuksen metodologian soveltamista äänilevyihin. Etenkin modernin etnomusikologian suhde koko diakroniseen näkökulmaan on ollut ongelmallinen (vrt. Rice 1987; Shelemay 1987; Kurkela 1991, 86-89; Blum 1993). Kaikesta huolimatta kaupalliset äänitteet ovat parhaimmillaan erinomainen, verraten vähän käytetty tutkimuskohde ja lähdeaineisto.

Lähteeksi käyviä äänitetyyppejä on lukuisia. Julkaistavaksi tarkoitetusta kappaleesta on ollut tapana äänittää useita otoksia, joista paras pääsi markkinoille. Yleensä toisintaotosten matriisit tuhottiin, mutta osa niistä päätyi levyyhtiöiden arkistoihin ja myöhemmin uusintajulkaisuille. (Gronow 1991, 232-233). Kaikkia studioäänitteitä ei ole alun perin tarkoitettu julkaistavaksi. Näihin kuuluvat Django Reinhardtin ensimmäiset kokeiluluontoiset kitarasoolot vuodelta 1934 (ks. Delaunay 1961, 65, 172). Tämänkaltaisilla äänitteillä on tutkimuskäyttöä: Elvis Presleyn ensimmäiset pikalevyt ja etenkin hänen Sunyhtiön studiossa 1954 tekemänsä harjoitusnauhat ja keskeneräiset otokset auttavat rekonstruoimaan julkaistujen tulkintojen synnyn (Gronow et al. 1990, 269-270).

On olemassa myös mainoslevyjä sekä propagandalevytyksiä ja armeijoiden omaan käyttöön tarkoitettuja levyjä (Gronow et al. 1990, 243-246). Oman ryhmänsä muodostaa elokuvamusiikki, joka ei ole aina päätynyt levylle asti. Myös radioasemat ovat taltioineet musiikkia suorista lähetyksistä pikalevyille tai ääninauhoille muuta kuin äänitetuotantoa varten. Näitä äänitteitä on myöhemmin 
julkaistu. Esimerkiksi vuosisadan merkittävin klezmer-klarinetisti Dave Tarras soitti kolmen eri newyorkilaisen radioaseman jiddišinkielisissä ohjelmissa, joiden musiikkiosuuksia taltioitiin ja myöhemmin julkaistiin (ks. Sapoznik 1991). Myös Suomen Yleisradiossa ennen 1960-lukua äänitettyä musiikkia on päätynyt CD-levylle (esim. Radio Suomi CDY 163).

Koska äänilevyteollisuus levisi länsimaiden ulkopuolelle jo varhain, monet vanhat levytykset sisältävät korvaamatonta materiaalia, dokumentteja jo hävinneistä musiikkikulttuureista ja perinnelajeista, joita ei voisi juuri tutkia muuten kuin äänilevyjen avulla (ks. Gronow 1981; Racy 1976, 23; 1988). Äänilevyjen lähdearvo onkin suurimmillaan tutkittaessa seikkoja, joista perinteiset kirjalliset lähteet kykenevät puhumaan vain vähän tai ei ollenkaan. Tällaisia tutkimusaiheita ovat esityskäytäntö ja sen muutos sekä improvisointitekniikat. Muistinvaraisen, runsaasti improvisointia sisältävän afroamerikkalaisen musiikin tutkijalle äänitteet ovat olleet jo pitkään tärkein lähdemateriaali (ks. esim. Lilliestam 1988). Sen sijaan länsimaista taidemusiikkia on totuttu pitämään kirjoitettuja kulttuurina, joten sen tutkimus on pitkälti perustunut säveltäjän laatimaan nuottikuvaan.

Äänitteiden tutkiminen avaa täysin uusia näkökulmia tutkimusperinteisiin, jotka ovat olleet kirjallislähtöistä. Hyviä esimerkkejä ovat länsimainen taidemusiikin sekä katolisen ja ortodoksisen kirkkomusiikin tutkimus. Ferruccio Busonin (1866-1924) 1910-luvun levytykset ja pianorullatallenteet antavat käsityksen vielä 1800-luvulla yleisestä nuottikuvan vapaasta tulkinnasta (ks. Sitsky 1986, 326-333). Pablo de Sarasaten (1844-1908) ja Joseph Joachimin (1831-1907) kaltaisten virtuoosien levytykset auttavat viime vuosisadan eurooppalaisten viulunsoiton koulukuntien tutkimisessa (ks. Pearl GEMM CD 9101; Pearl GEMM CD 9102). Viimeisiin kastraattilaulajiin kuuluneen Alessandro Moreschin (1858-1922) vuosina 1902 ja 1904 (Pearl Opal CD 9823) sekä Konstantinopolin patriarkaatin kuuluisan protopsaltisin Jakovos Nafpliotisin (1864-1942) hieman myöhemmin tekemät levytykset (esim. Orfeon 11614) sisältävät nekin runsaasti nykyajalle vieraita esityskäytäntöjä.

On kuitenkin tärkeä muistaa, ettei varhaisten äänitteiden lähdearvo ole yksiselitteinen asia. Äänitystekniikan rajoitusten vuoksi vuosisadan alkupuolella levyttäneiden soittajien täytyi muuttaa tyyliään normaalista. Myös levyjen vaihtelevat kierrosnopeudet sekä tempovalintoihin ja kokonaisuuksien pituuksiin vaikuttaneet rajalliset kestot vaikeuttavat tutkimusta. (Ks. Muikku 1994, 24). Siksi varhaisten äänitteiden ja niiden uusintajulkaisujen tutkimuskäyttö vaatii tarkkaa lähdekritiikkiä.

Lähdeaineiston luotettavuuden arvioimista tarkoittava lähdekritiikki on historiantutkimuksen metodiopin tärkeimpiä puolia. Lähdekritiikin tehtävänä on paljastaa lähteiden ja tutkimusongelmien väliset suhteet sekä asettaa lähteet tutkimuksellisen käyttökelpoisuuden mukaiseen tärkeysjärjestykseen. Kritiikki jakautuu ulkoiseen ja sisäiseen. Ulkoinen lähdekritiikki merkitsee lähteen historiallisen synty- ja vaikutusympäristön määrittämistä, ja se mahdollistaa 
sisäisen lähdekritiikin harjoittamisen. Tämä on lähteen antamien tietojen todellisuuspohjan selvittämistä. Tietoja punnitaan lähteen tarkoituksen kannalta, jotta saataisiin selville, paljonko tiedoissa on lähteen tehtävän tai aseman vaikutusta ja paljonko sellaista, joka perustuu todellisuuteen. (Dahl 1970, 51; Renvall 1983, 166).

\section{Ajoitus ja diskografia}

Ulkoinen lähdekritiikki pyrkii määrittämään dokumentin syntyajan ja -paikan sekä sen laatijan ja vastaanottajan. Se pohtii, onko dokumentti todella sitä, miltä se näyttää ja liittyykö dokumentti kokonaisuudessaan vain yhteen menneisyyden kohtaan vai onko se syntynyt useammassa vaiheessa. (Renvall 1983, 167).

Parhaassa tapauksessa itse 78-kierroksinen levy fyysisenä objektina kertoo jo paljon. Levyetiketin väri ilmaisee usein julkaisusarjan. Levyn koosta, reunan muodosta, yksi- tai kaksipuoleisuudesta sekä tyhjästä alkuraidasta tai sen puuttumisesta voi ryhtyä päättelemään julkaisuajankohtaa. Levyetiketti ilmoittaa teoksen nimen, levy-yhtiön, sekä luettelo- ja matriisinumeron ja usein myös äänitys- ja valmistusmaan, säveltäjän, sanoittajan, sovittajan, muusikot, tuottajan, soittimet, teoksen moodin (esim. makam rast) ja lajityypin sekä äänitteen kohderyhmän kielen. (Vrt. Strötbaum 1992, 150-152). Luettelonumeron vertaaminen diskografiatietoihin paljastaa julkaisuvuoden. Ikävä kyllä useimmista maista ja musiikinlajeista ei ole olemassa kattavia diskografioita. Matriisinumero ilmoittaa äänitysajankohdan, mikäli tutkija pystyy vertaamaan sitä valmiisiin diskografioihin, jo ajoitettuihin matriisinumeroiltaan läheisiin levyihin tai levy-yhtiön arkistotietoihin.

Ajoituksessa voi joutua turvautumaan myös levyn soivaan sisältöön. Mikäli äänite on akustinen eikä mikrofonilla tehty, se on vuotta 1925 edeltävältä ajalta. Siksi akustisesti äänitetty 78-kierroksinen levy, jonka luettelonumero viittaa vaikkapa vuoteen 1928, on mitä todennäköisimmin uusintajulkaisu. Ajoituksen apuna voivat olla myös viittaukset joihinkin tapahtumiin (teoksen nimi ja lauluteksti) tai sitaatit aiemmista, ajoitetuista levytyksistä (teksti ja musiikki). Vaativimmillaan diskografinen tutkimus on todellista salapoliisityötä, kuten käy ilmi Hugo Strötbaumin (1992) ansiokkaasta saksalaisen Favourite Recordsin Lähi-idän julkaisuihin keskittyvästä tutkielmasta.

Äänitys- ja julkaisuajankohdan selvittäminen vaatii perehtymistä diskografiseen tutkimukseen (ks. Rust 1980; Gronow 1991, 231-234). Taitamaton diskografi päätyy helposti harhapäätelmiin. Vuonna 1976 Tasos Shorelis toimitti varhaisten Yhdysvalloissa Columbia-yhtiölle tehtyjen rebetika-levytyksien kokoelman (CBS 53753). Hän ilmoittaa levyn oheistekstissä ajoittaneensa kunkin kappaleen täsmällisen levytyspäivämäärän, koska tuo tieto on painettuna levyetiketteihin. Hänen mukaansa levytykset on tehty vuosina 1900-1913. Ottakaamme esimerkiksi Marika Papagikan levyttämän laulun "Smirneiko balos". 
Levyetiketissä on teksti "Made and Pat. Nov. 12. '01", joten Shorelis ajoittaa äänitteen tekopäiväksi 12.1.1901. Näin varhainen, akustista äänitettä edellyttävä levytysajankohta ei kuitenkaan tunnu uskottavalta, koska kappale on laajasta dynamiikasta ja toistoalueesta päätellen taltioitu mikrofonin avulla. Muutenkin ajankohdan varhaisuus tuntuu oudolta. Pääsivätkö Yhdysvaltain siirtolaismuusikot tosiaan levyttämään kansan- ja populaarimusiikkiaan jo näin varhain? Olisiko levytys tehty muualla ja puristettu levyksi Uudella mantereella?

Marika Papagikan henkilöhistoriasta käy ilmi, että hän syntyi Kosin saarella 1.9.1890, asui jonkin aikaa Egyptissä ja muutti Yhdysvaltoihin 1913 (Soffa 1994, 19). Shorelisin ajoituksen mukaan laulajattaren olisi siis pitänyt levyttää kappale 11-vuotiaana, kauan ennen Yhdysvaltoihin muuttoa. Shorelis ei ole liittänyt uusintajulkaisuunsa alkuperäislevyn matriisi- ja luettelonumeroita, mutta ne saa tietoonsa Yhdysvaltain etnisten levytysten diskografiasta (Spotswood 1990): "Smirneiko balosin" matriisinumero on 205371-2 ja luettelonumero Columbia 56034-F. Näiden tietojen perusteella levytys näyttää tehdyn vuonna 1926, mikä täsmää mikrofoniäänityksen ja Papagikan iän kanssa.

Mikä sitten merkitsee levyetiketin merkintä 'Made and Pat. Nov. 12. '01", jota Shorelisin piti levytyspäivämääränä? Äänilevyn alkuvuosikymmeninä Yhdysvalloissa oli tapana hankkia yksinoikeuksia esimerkiksi äänitysteknisiin ratkaisuihin, levymassan koostumukseen ja jopa etikettien väriin (Pekka Gronow, haast.). "Made and Pat. Nov. 12. '01" merkitsee siis sitä, että Columbia patentoi 12.1.1901 jonkin seikan, jota se käytti levyissään vielä vuonna 1926. Patentin kohde selviäisi tutkimalla Columbian historiikkia.

"Smirneiko balosin" ajoitusongelma ilmentää periaatetta, jonka mukaan lähteiden tarkastelu perustuu niiden keskinäiseen vertailuun suuremmassa lähdejoukossa. Yksittäistä lähdettä voidaan hyödyntää vain, jos sitä vertaillaan muihin lähteisiin ja historiallisiin lähteisiin. (Dahl 1970, 41). Siksi myös tiettyä äänilevyä ja sen sisältämää äänitettä tulee vertailla muihin tutkimuksen kannalta käyttökelpoisiin levyihin ja äänitteisiin sekä muista lähderyhmistä - haastatteluista, kirjallisuudesta,valokuvista ja elokuvista - saatuihin tietoihin.

\section{Äänitteen aitous}

Historiallisen asiakirjan ja äänitteen aitous eivät ole olleet sama asia siitä lähtien kun trikkiäänitykset ja moniraitanauhurit otettiin käyttöön. Nykyaikainen studiotyöskentely kuuluu pitkälle taiteen piiriin, eikä sitä voi arvottaa suoraviivaisen lähdekritiikin avulla. Siksi äänilevyjen lähdekriittinen tarkastelun täytyy ottaa huomioon studiotekniikan avulla tuotetun musiikin erityisluonne. Magnetofonien käyttöönoton jälkeen äänitteet menettivät osan aiemmasta suorasta suhteesta todellisuuteen; muusikot kykenivät mielin määrin muuttamaan nauhalle tallennettua esitystään. Pekka Gronowin ja Ilpo Saunion $(1970,122) \mathrm{mu}$ kaan esimerkiksi kapellimestari Arturo Toscaninin (1867-1957) levyttämät 
klassiset tulkinnat syntyivät useiden toisiinsa yhdistettyjen otosten avulla. Studiotekniikan käytön vei huippuunsa yhdysvaltalainen tenori Mario Lanza (1921-1959), joka kykeni laulamaan ajoittain kuin Caruso, mutta loisteliaiden jaksojen välissä oli teknisesti kelvotonta äänenkäyttöä. Siksi hänen levynsä koottiin studiotekniikan avulla. (Ibid.; ks. myös Rust 1980, 13).

Lähdekritiikin periaatteiden mukaan lähteen antamien tietojen tulee sopia yksiin keskenään tai muiden lähteiden antamien tietojen kanssa. Mikäli näin ei käy, täytyy turvautua aiempaa tiukempaan lähdekritiikkiin. Mikäli ristiriita ei kaikesta huolimatta häviä, lähteestä saatua käsitystä täytyy muuttaa. Lähde ei olekaan se, miltä se näyttää, vaan epäaito. (Dahl 1970, 44-45; Renvall 1983, 187).

Epäaitoutta on monenlaista. Dokumentti on voitu laatia kokonaan muuna aikana kuin miltä sen pitäisi olla peräisin. Tällöin kyseessä on väärennös. Dokumentista on voitu myös poistaa jotain tai siihen on voitu lisätä jotain. Tällöin dokumentti on vääristelty tai vääristynyt. Näissä tapauksissa dokumentin sisältämän informaation todistusvoima on toisenlainen kuin aidon, alkuperäisen ja ehyen dokumentin. Siitä huolimatta tällaista dokumenttia voi käyttää lähteenä. Tosin tällaisen dokumentin tehtävät eivät ole samoja kuin aidon ja ja ehyen. Kun olemme paljastaneet dokumentin epäaitouden, pyrimme selvittämään sen todellisen tehtävän ulkoisen lähdekritiikin avulla. Tämän jälkeen voimme arvioida sen sisältämien tietojen käyttökelpoisuutta. (Renvall 1983, 187-188).

Esimerkkinä tietoisesta vääristelystä käy sensuuri. The Beatles -yhtyeen "Sgt. Pepper's" -levyn päättävä takaperoinen seksuaali-ilkamointi poistettiin joistain 1970-luvun lopun painoksista. Nähtävästi väärin päin soivan viestin sisältö ${ }^{1}$ loukkasi levy-yhtiön päättäjiä. He saattoivat sensuroida levyä myös tehdäkseen siitä riskittömämmän myyntiartikkelin. Näitä sensuroituja painoksia ei voisi käyttää "Sgt. Pepper's" -kokonaisuuden tutkimiseen. Sen sijaan ne kertoisivat jotain tutkijalle, joka on kiinnostunut 1960-luvun vapaamielisen hippikulttuurin ja sitä 1970-luvulla seuranneen konservatiivisen moralismin keskinäisistä suhteista.

Väärennöksen paljastaminen käy seuraavalla tavalla. Mikäli sisällön jotkut kohdat poikkeavat vastaavista asioista yleensä tiedetyn kanssa, vertaamme väärennökseksi epäilyksen alaisen dokumentin ulkonaisia piirteitä muihin asiakirjoihin. Vertailu tehdään kaksisuuntaisesti: tutkitaan muita alkuperältään samoja dokumentteja ja toisaalta muita dokumentteja, jotka kuuluvat siihen historialliseen ympäristöön, josta arvelemme väärennöksen olevan peräisin. Näin pääsemme selvyyteen väärennökselle annetusta tehtävästä. (Renvall 1983, 188).

Seuraavassa esimerkissä ei ole kysymys tietoisesta väärennöksestä, vaan inhimillisestä erehdyksestä. On tiettävästi olemassa vain yksi äänite, jolla Jean

1 "'I'll fuck you like a superman." 
Sibelius johtaa omaa teostaan. Yleisradion pikalevylle 1.1.1939 taltioima huomattavan hidastempoinen "Andante festivo" julkaistiin ensimmäisen kerran vuonna 1972 (Scandia SLP-567), ja siitä lähtien se on ollut ainutlaatuisen dokumentin maineessa. Ainakin Erik Tawaststjerna $(1988,116-117)$ on käyttänyt sitä lähteenä hahmotellessaan Sibeliuksen johtamistyyliä ja käsitystä omasta tuotannostaan. ${ }^{2} 1995$ paljastui, ettei tämä äänite ollutkaan se, mikä sen sanottiin olevan. Yleisradion arkistoista löydetty oikea Sibeliuksen johtama "Andante festivo" ei ole aivan niin hidas kuin nimettömäksi jääneen toisen kapellimestarin johtama epäaito, joka oli vienyt arkistoitaessa aidon paikan. Löydetyn Sibelius-tulkinnan aitouden paljasti säveltäjän nuottikäsikirjoitukseen tekemä muutos, jota ei ole julkaistussa partituurissa eikä myöskään epäaidossa levytyksessä. Uudenvuodenpäivänä 1939 Sibelius johti käsikirjoituksen pohjalta, joten äänitteellä on mukana hänen tekemänsä muutos. (Karttunen 1995).

\section{Uusintajulkaisut lähteinä}

Alkuperäislevyjen hankkiminen tutkimuskäyttöön ei ole aina helppoa. Levyjä voi ostaa osto- ja myyntiliikkeistä sekä levyhuutokaupoista. Levytysten kopioita voi saada muusikoiden ja keräilijöiden yksityiskokoelmista tai arkistoista sekä julkisista tai levy-yhtiöiden arkistoista. Tutkimusmateriaalin hankinta käy kuitenkin helpoiten uusintajulkaisujen avulla. Markkinoilla on monia hyvinkin laajoja julkaisusarjoja. Kreikan johtavan diskografin Panajotis Kunadisin toimittamasta historiallisia rebetika-äänitteitä sisältävästä antologiasta "Arhio ellinikis diskografias" eli "Kreikkalaisen diskografian arkisto" (EMI-Minos 1994-) on kaavailtu peräti yli sataosaista (sarjasta lähemmin, ks. Pennanen 1995).

Historiallisen musiikintutkimuksen kannalta laajojen, hyvin toimitettujen lähdekokoelmien julkaiseminen on erittäin tärkeää. Yleisen historiantutkimuksen tieteellisten vaatimusten pohjalta toimitettuihin lähdejulkaisuihin verrattuna etenkin populaarimusiikin uusintajulkaisut ovat hyvin usein auttamattoman heikkotasoisia. Syynä tähän lienee se, että populaarimusiikin musiikkitieteellinen tutkimus on nuorta. Muutenkaan levy-yhtiöt eivät ole katsoneet vanhaa populaarimusiikkia vaivalloisen toimitustyön arvoiseksi. Tarkan alkuperäisen tai alkuperäiseen asuun palautetun äänitteen sijasta uusintajulkaisuilla saattaakin olla vääristelty tai vääristynyt dokumentti. Useimmat uusintajulkaisut eivät

\footnotetext{
2 Tawaststjerna (1988, 116-117) kirjoittaa lähdettään ilmoittamatta, että uudelleen julkaistu "Andante festivo" tallennettiin radiolähetyksestä New Yorkissa. Yhdysvalloissa tapahtunut tallennus ei liene erityisen todennäköinen esimerkiksi lyhytaaltoliikenteen häiriöiden vuoksi. On jokseenkin varmaa, että tulkinnan verkkaista tempoa ylistävä Tawaststjerna analysoi epäaitoa Sibelius-äänitettä.
} 
myöskään sisällä edes diskografisia perustietoja eivätkä äänitteiden taustaa valottavia lähdeviittein varustettuja kommentaareja. ${ }^{3}$

Jo uusintajulkaisujen äänieditoinnissa on ongelmia. Äänenlaadultaan ylivoimaiset alkuperäismatriisit ovat yleensä syystä tai toisesta saavuttamattomissa, joten äänitteet voidaan vain aniharvoin siirtää uuteen formaattiin suoraan niiltä (ks. kuitenkin Traditional Crossroads CD 4266). Siksi useimpien uusintajulkaisujen pohjana ovat vaihtelevan kuntoiset shellakkalevyt. Formaatista toiseen siirtäminen on vaativa tehtävä. Ei ole ihme, että monien julkaisujen äänieditointi on kaikkea muuta kuin esimerkillistä. Ennen 1950-luvun puoliväliä tehdyt äänitteet siirretään hyvin usein uusintajulkaisulle modernia RIAA-toiskäyrää käyttäen. Alkuperäisen ja modernin käyrän sointiero saattaa olla huomattava. (Ks. Gronow 1991, 231).

Myös vanhojen levyjen standardeista poikkeavat kierrosnopeudet saattavat olla pulmallisia editointityössä. Esimerkistä käy Eugen Malmsténin johtama Rytmi-Kolmosten ja Rytmi-Poikien levytys "Heipä hei" (matriisi 6180 1/2 GR; luettelo Polydor S.50463 A) vuodelta 1935. Sen kesto LP-levyllä (Sound Cat MILP-197) uudelleen julkaistuna on 3:08, mutta CD-llä (Sound Cat MICD-197/198) 3:14. Jo edellinen julkaisu kuulostaa oudolta. Puhaltimista puuttuu heleys, eikä melko möreä-äänistä laulusolistia heti tunnista Eugen Malmsténiksi. Jälkimmäisessä julkaisussa nämä piirteet korostuvat entisestään.

"Heipä hein" äänittäneet teknikot olivat maassamme vierailevia saksalaisia ammattimiehiä, joilla oli käytössään siirrettäviä äänityslaitteita. Näiden laitteiden pyörimisnopeutta oli vaikea hallita, ja se saattoi muuttua esimerkiksi jännitteen vaihtelun vuoksi. Levyleikkurin pyörimisnopeus saattoi siis olla jokin muu kuin standardiksi vakiintunut 78 kierrosta minuutissa. Kun "Heipä heitä" soittaa standardinopeudella, sen sävellaji asettuu D-duurin ja Es-duurin väliin, mikä ei ilmeisesti voi olla oikein. Uusintajulkaisu-LP:n toimittaja on tyytynyt siirtämään "Heipä hein" sellaisenaan levylle. CD:n toimittaja on huomannut virheen ja ottanut lähtökohdakseen kiinteävireisten soittimien viritystason. Hän on laskenut sen D-duuriin, vaikka tällöin B-vireisten puhaltimien soittajat olisivat joutuneet soittamaan hankalassa E-duurissa. (Gronow, haast.; Wuori 1994). Puhallinsävellaji sekä Eugen Malsténin lauluäänen sointi viittaavat siihen, että oikea sävellaji olisi ollut Es-duuri. Äänitettä olisi siis pitänyt nopeuttaa eikä hidastaa.

Kierrosnopeuden muuttaminen nykyisen konserttivirityksen mukaiseksi on usein perusteetonta, koska uusintajulkaisun editointityö ei tarkoita vanhojen

3 Joel Rubinin ja Rita Ottensin klezmer-tutkimusprojektin yhteyteen laatima CD-levy "Yikhes. Frühe Klezmer-Aufnahmen von 1907-1939 aus der Sammlung von Prof. Martin Schwartz"' (Trikont US-0179) on erinomainen esimerkki huolella tehdystä ja kommentaarein varustetusta uusintajulkaisusta. 
äänitteiden alkuperäisen säveltason muuttamista nykykäytäntöä vastaavaksi. Esimerkiksi studion lämpötila vaikuttaa myös kiinteävireisten soitinten viritykseen. Editoinnin päämääränä tulee tietysti olla äänitteen saattaminen kuntoon, jossa sen sisältämä informaatio on alkuperäisesitykseen nähden maksimaalista ja vääristymätöntä. ${ }^{4}$ Poikkeamat alkuperäisestä dokumentista aiheuttavat tutkijalle monenlaisia ongelmia. Äänitteen sointi ja tempo eivät vastaa alkuperäistä, ja kiinteävireisten soittimien soittotekniikan analyysi tuottaa vääristyneitä tuloksia.

Monien historiallisten äänitteiden äänenlaatua voidaan parantaa äänieditoinnin avulla. Äänirestaurointi saattaa tuoda esille aiemmin huonosti kuuluneita tai jopa peittoon jääneitä soitinosuuksia. Lisäksi se saattaa korjata äänitystekniikan rajoitusten aiheuttamia vääristymiä. Runsaasti levyttäneen Enrico Caruson (1873-1921) laulutekniikan puutteina pidettiin pitkään äänenvärin muuttumista rekisterin yläpäässä. Käsitys perustui levytyksiin; aikalaislähteet eivät puhu asiasta mitään. Levytysten restauroinnin jälkeen puutteellisuuksien on tajuttu johtuneen äänityssuppiloiden resonanssista. (Ks. Gronow et al. 1990, $60)$.

Taitamaton editointi vaikeuttaa nuotinnustyötä ja musiikkianalyysia. Laulajatar Roza Eskenazin, viulisti Dimitris Semsisin ja ud-luutisti Agapios Tombulisin 1930 Ateenassa levyttämä "Rast kanto An den me pistevi" (Odeon GA 1453) on julkaistu uudelleen CD-levyllä (Minos-EMI 724348 04102 9). Alkuperäislevy on harvinaisuus, joten tutkijan on tyytyminen uusintajulkaisuun. Teoksen tahtilajin tai rytmimoodin määrittäminen on yllättävän vaikeaa; painolliset tahdinosat tuntuvat kaihtavan säännöllisyyttä.

Lajinimestä "kanto" voi päätellä teoksen kuuluvan vuosisadan alun Anatolian suurkaupunkien Istanbulin ja Izmirin populaarimusiikkiin (ks. Ayangil 1994). Koska kanto-perinne oli populaarimusiikkia, se ei ole kuulunut Turkin valtion tukemiin musiikinlajeihin, eikä se ole kiinnostanut musiikintutkijoita. Alkuperäisiä vuosisadan alkukymmenten levytyksiä on julkaistu uudelleen vain muutamia (ks. Ocora C 560081). Koska etukäteistietoa kanto-laulujen musiikillisista ja etenkin rytmiominaisuuksista on saatavissa vain vähän, "An den me pistevia" nuotintaessa ei voi kokeilla perinteen mukaisten todennäköisten rytmimoodien soveltuvuutta. Kuullun perusteella tahtilajiksi tuntuisi sopivan 16/4 (esim. 1a). Kolmannesta tahdista alkava tahtilajien vaihtelu $(15 / 4,16 / 4)$ ei kuitenkaan tunnu luontevalta eikä tyylin mukaiselta. Kantot olivat populaarilauluja, joten niiltä odottaisi lyhyitä rytmimoodeja ja säännönmukaisuutta.

4 Oikean kierrosnopeuden ja viritystason löytäminen on erityisen pulmallista, mikäli editoija joutuu käsittelemään ainutlaatuista, vailla vertailukohtia olevaa materiaalia. Ainoan levyttäneen kastraattilaulajan Alessandro Moreschin tuotanto kuuluu tällaisiin ongelmatapauksiin, koska editointityön alussa kukaan ei tiennyt, miltä kastraattiäänen tulisi kuulostaa (ks. Wolfson 1987). 
Ristiriita rytmisen epäsäännöllisyyden ja populaarin välillä tuntuu suurelta, joten on turvauduttava äänitteen ulkoiseen lähdekritiikkiin. Mitäpä, jos teos ei olekaan uusintajulkaisulla kokonaisuudessaan? Ensimmäisen tahdin lopussa oleva g1: stä alkava juoksutus johtaa painoa saavalle d2-sävelelle, joka on funktioltaan tärkeä makam rastissa. Myös toisen tahdin kolmas sävel d2 painottuu. Näiden kahden sävelen välille syntyy luontevasti neli-iskuinen tahti, ja neli-iskuisuus tuntuu jatkuvan luontevasti läpi teoksen lauluosuuden, jota seuraa nopea kaksijakoinen tanssiosuus. Alkusoiton nelijakoisuus paljastuu määrittelemällä kunkin tahdin pääpainot ensimmäiseksi löydetystä painollisesta d2-sävelestä taaksepäin. Koska soitinosuus näyttää perustuvan kertaukseen, teoksen uusintajulkaisulta pois jäänyt ensimmäinen tahti on luultavasti korjatun nuotinnoksen (esim. 1b) mukainen. Kohotahti on luultava, koska se on yleinen lauluosuudessakin. Uusintajulkaisulle päätyneen "An den me pistevin" osan pituus on normaalikokoisen 78-kierroksisen levyn enimmäiskestoa lähestyvä $3: 14$, joten soitinosuudesta ei voi puuttua kuin muutaman sekunnin mittainen jakso.
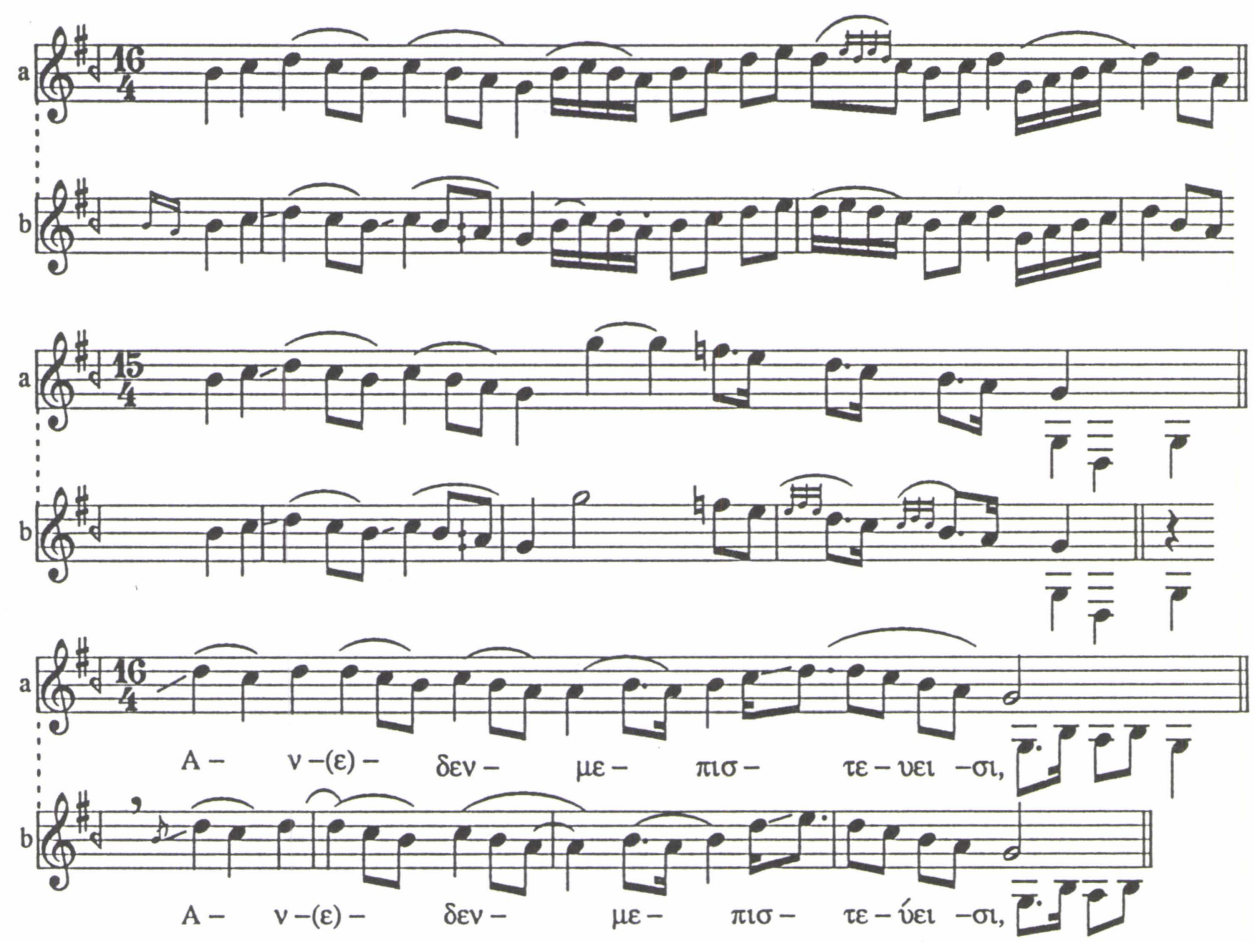

Esimerkki 1. a) Osa rast-kanton "An den me pistevi" ensimmäisestä (Marko Jouste) ja b) toisesta nuotinnoksesta (Marko Jouste, Jarkko Niemi ja prof. Yalçın Tura). 
Miksi nuotintaminen vaati näin mutkikasta päättelyä ja rekonstruktiota? Syynä oli lähdejulkaisun heikkotasoisuus. Se ei tarjonnutkaan äänitteitä sellaisina kuin ne ovat alkuperäislevyillä. Asian voi varmistaa julkaisun muista äänitteistä; useat niistä alkavat nostolla kesken alkusoiton. Uudelleenjulkaisun lähdearvosta jää päätelmäksi, ettei toimittaja ole perehtynyt musiikintutkimukseen eikä ilmeisesti ole tarkoittanut julkaisusarjaa tutkimuskäyttöön. Siksi sen käyttö lähteenä vaatii varovaisuutta ja tarkkaa lähdekritiikkiä.

Uudelleenjulkaisujen ääniteknologisen sekä diskografisen toimitustyön heikkotasoisuus tuntuu vaivaavan erityisesti kreikkalaista populaarimusiikkia (ks. Smith 1989; 1991). 1970-luvulla rebetika-renessanssin alkuaikoina uudelleenjulkaisujen toimittajalla Kostas Hadzidulisilla oli tapana päättää kappaleet häivytykseen, mikä vähentää äänitteen lähdearvoa (ks. esim. EMI Regal 14C 034-70364). Kuulijalle jää arvoitukseksi, miten alkuperäisäänite loppuu. Häivytetty jakso on hyvinkin saattanut sisältää tutkimuksen kannalta tärkeää informaatiota, kuten muusikoiden nimet sisältäviä huudahduksia. Häivytys on ollut länsimaisten poplevytysten yleisin päätöstapa 1960-luvulta lähtien. Siksi Hadzidulis pyrki antamaan vanhoille äänitteille modernin ilmeen häivytyksen avulla.

\section{Sisäinen lähdekritiikki: Mistä varhaiset kaupalliset levytykset to- della kertovat?}

Sisäisen lähdekritiikin tehtäviin kuuluu selvittää, mitä dokumentti todistaa tai voi todistaa todellisuudesta, siis missä määrin asiakirjassa oleva tieto vastaa todellisia oloja. Sisäisen lähdekritiikin tärkein tehtävä ei kuitenkaan ole asiakirjan luotettavuuden tai epäluotettavuuden punnitseminen, vaan asiakirjan kertomien asioiden todistusvoiman ja paikkansapitävyyden määrittely. (Renvall $1983,203,198)$.

Millaista todistusvoimaa ja paikkansapitävyyttä varhaisilla äänilevyillä sitten on? Voisi väittää, etteivät varhaiset kaupalliset levytykset ole suoranaisia dokumentteja vallinneesta musiikkikulttuurista, vaan monen tekijän kautta suodattuneesta levytetyn musiikin kulttuurista. Kaikki musiikki ei suinkaan päätynyt levylle, eivätkä levytetyn musiikin esityskäytäntö ja rakenne aina vastanneet studion ulkopuolista musiikkitodellisuutta (ks. Gronow 1982, 16). Esimerkiksi Itä-Euroopassa kansanomaisen tanssiyhtyeen tärkeimmät ominaisuudet ovat olleet laaja ohjelmisto ja kyky soittaa tanssittavasti. Tanssikappaleet ovat koostuneet muutamasta taitteesta, joita on kerrattu uudelleen ja uudelleen enemmän tai vähemmän muunnellen. Yksi kappalekokonaisuus on voinut kestää hyvinkin jopa 45 minuuttia, mikäli tanssijat ovat vaatineet niin. 78-kierroksisten levyjen kolmesta neljään minuutin soittoaika rajoitti kappaleiden pituutta ja rakenteen vapautta. Kaupallisista syistä näille lyhennetyille tanssikappaleille piti keksiä myös nimet. Alkuperäiskontekstissaan klezmer-repertoaari koostui lähinnä perinnelajin mukaan nimetyistä kappaleista, kuten "Freilachs", 
"Hora" ja "Chosid'1". New Yorkin studioissa ne saivat uudet tarkemmat nimet, vaikkapa "Yiddish hora - a heymish Freylekhs" tai "Dem monastrishter Rebins Chosid'1". (Slobin 1984, 194-195; Sapoznik 1987, 12; vrt. Muikku 1994, 21).

Äänilevyjen myynti Yhdysvalloissa kasvoi tasaisesti ennen ensimmäistä maailmansotaa ja nousi jyrkästi sen jälkeen. 1910-luvun alussa myynti oli noin 30 miljoonaa kappaletta, vuonna 1921 noin 140 miljoonaa kappaletta ja vuonna 1929 juuri ennen suuren talouspulan tuomaa romahdusta noin 150 miljoonaa kappaletta. (Gronow 1983, 59, 63). 1914 Victorin ja Columbian omistamat äänilevyteknologian yksinoikeudet olivat murtumassa, ja alalle pyrki uusia yrittäjiä. Yhtiöt kilpailivat kasvavista markkinoista äänentoiston laadun ja levysoitinten muotoilun sekä pakon saneleman oman äänitetuotannon avulla. Levyyhtiöt kuuluivat lähinnä sähkötarviketeollisuuteen, eikä niillä yleensä ollut läheisiä suhteita musiikkibisnekseen tai itse muusikoihin. Tämän vuoksi musiikkitilaisuuksien järjestäjät kykenivät ohjailemaan yhtiöiden julkaisupolitiikkaa. Etenkin populaarimusiikkituotanto koostui suosittujen esiintyjien moneen kertaan levyttämistä uusimmista suosikkikappaleista. Vain harvat yhtiöt olivat kiinnostuneita uusista esiintyjistä ja tuntemattomista sävelmistä. (Frith 1988, $15)$.

Levyautomaattien yleistyminen Yhdysvalloissa 1930-luvulla johti ensi kertaa tilanteeseen, jossa äänilevy alkoi muokata populaarimusiikin kuluttajien makua. Samalla syntyi tähtikultti, joka vahvisti äänilevyn, äänielokuvan ja radion keskinäistä riippuvuutta. Levy-yhtiöt kiinnostuivat uusien musiikkimakujen luomisesta, kysynnän ohjailuista. (Ibid., 16, 18-19).

Tästä huolimatta varhainen äänilevy Yhdysvalloissa vaikutti monien etnisten ryhmien musiikkiperinteiden säilymiseen ja kehitykseen (ks. Gronow 1982, 4). Sitä paitsi äänilevyn tekniset rajoitukset ovat vaikuttaneet kaikkeen levytettyyn musiikkiin. Ennen vuotta 1925 ja siirtymistä mikrofoniäänityksiin teknologia rajoitti levytyskokoonpanojen koostumusta ja pakotti muuttamaan esimerkiksi viulunsoittotekniikkaa normaalista. Ääniteknikot suosivat puhallinyhtyeitä, koska niiden soitto tallentui hyvin akustisille levyille, joten esimerkiksi levytetyt ragtime-pianosoolot eivät olleet aluksi yleisiä musiikkityylin pianopohjaisuudesta huolimatta. Ääniteknologian kannalta soolobanjo ja sitä säestävä piano oli soolopianoa parempi kokoonpano (vrt. Muikku 1994, 22-23). Nähtävästi äänilevyteollisuus vaikutti mainitun kaltaisissa tapauksissa joidenkin soitinkokoonpanojen yleistymiseen. Siltikään vanhat levytykset eivät välttämättä kerro meille, mitkä soittimet ja esityskäytännöt olivat yleisimpiä klezmer- ja ragtime-musiikissa studioiden ulkopuolella (Sapoznik 1987, 12; Berlin 1980, 78, 149). 1925 käyttöön otettu yksimikrofoninen äänitystekniikka laajensi äänilevyn toistoaluetta ja paransi dynamiikkaa. Myös suurten kokoonpanojen ja konserttitilanteiden taltioiminen tuli mahdolliseksi (Borwick 1995). Niinpä mikrofoniäänitykset ovat usein lähempänä elävän musiikin todellisuutta kuin aiemmat akustiset vastineensa. 
Kaupalliset levytykset vaikuttivat myös musiikin tyyliseikkoihin. Levytysten kautta levinneet uudet ideat, tyylit, tulkintatavat, tekniikat ja yksittäiset teokset saattoivat yleistyä ja jopa syrjäyttää edeltäjiään. Hyvä esimerkki ideainnovaation leviämisestä levymarkkinoilla on kuplettilaulaja Ewgen Zukowskyn, laulajatar Nasza Roza Krasnowskan sekä viulisti Pawlo Humeniukin vuonna 1926 New Yorkissa levyttämä "Ukrainske wesilia" (Columbia 70002) eli "Ukrainalaiset häät", kahden levypuoliskon mittainen kuulokuva perinnehäistä. ${ }^{5}$ Kahdeksaan minuuttiin puristettu hääjuhla sisälsi vieraiden saapumisen, naittajan puheen, morsiamen äidin valituksen, kirkonkellojen pauhinaa, hääparin siunauksen, morsiamen isän puheen, onnentoivotuksia, morsiamen ja hänen äitinsä itkun sekä runsaasti laulua ja tanssikappaleita. Tämä tehosi kotiikävää poteneisiin amerikanukrainalaisiin; levyä myytiin ehkä jopa yli 100000 kappaletta. "Ukrainalaiset häät" pysyi markkinoilla neljännesvuosisadan. Aikaansa nähden valtava myyntimenestys selittyy sillä, että muutkin siirtolaisryhmät ostivat sitä, vaikkeivät aina ymmärtäneetkään laulujen ja puheiden sisältöä. (Spotswood 1993). Vanhan mantereen muisto ei ollut vielä haalistunut ensimmäisen polven siirtolaisten mielistä.

"Ukrainalaiset häät" takasi levyttäjäkolmikolle studiouran, joka luonnollisesti sisälsi lisää menestyksekkäiden kuulokuvien levytyksiä (ibid.). ${ }^{6}$ 'Ukrainalaisilla häillä" oli laajempaakin vaikutusta levytetyn musiikin kulttuuriin: uusi äänitelaji oli syntynyt. Levy-yhtiöt alkoivat julkaista eri siirtolaisryhmille tarkoitettuja nostalgisia kuulokuvia, jotka sijoittuivat näiden kotimaihin. ${ }^{7} \mathrm{Sa}-$ malla kertaa siirtolaisten varsinainen perinnemusiikki pääsi levylle aiempaa huomattavasti useammin aikana, jolloin levy-yhtiöt Euroopassa vielä suosivat taidemusiikin estetiikalla tulkittuja pianosäesteisiä kansanlauluja (Gronow et al. 1990, 139).

On syytä pohtia kuulokuvien lähdearvoa sisäisen lähdekritiikin avulla. Näiden levytysten pohjalta ei liene mielekästä tutkia 1930-luvun eurooppalaista kansanmusiikkia ja kansanperinnettä. Useimmat kuulokuvista sisältävät eri paikalliskulttuurien piirteitä, joiden pohjalta on yritetty luoda romanttisen aatevirtauksen mukainen kansallinen kulttuuri. Voisi arvella, että kuulokuvat ovat levylle siirrettyjä kohtauksia kansannäytelmistä ja folkloristisista kuvaelmista, joita esitettiin siirtolaisten kotimaissa kansallismielisten yhdistysten ja myöhemmin Yhdysvalloissa siirtolaisyhteisöjen juhlissa. Esimerkiksi amerikan-

\footnotetext{
${ }^{5}$ Kaikki ukrainankieliset nimet ja sanat on translitteroitu puolan kielen ortografian mukaan, koska tämä oli käytäntönä amerikanukrainalaisilla levyillä.

6 Esimerkiksi "'Kihlajaisjuhla" ("Zaruczyny"), "Kastejuhla" ("Chrestyny"), "Häät räystään alla" ("Na wesiliu pid chatoju") sekä "Pyhiinvaelluksella Poczajewoon" ("Do Poczajewa na widpust") (ks. Arhoolie CD 7025).

7 Ernest Paanasen "Naimahommia 1-6" vuodelta 1929 (ks. KICD 34) suunnattiin suomalaissiirtolaisille.
} 
suomalaisten Kalevala-kerhot ovat olleet suunnilleen sitä, mitä Suomessa 1960-luvulla kutsuttiin tuohivirsukulttuuriksi (Simo Westerholm, haast.). Lähdeaineistona kuulokuvat kertovat siis kansanperinnekäsityksestä siirtolaisjärjestöissä.

\section{Lopuksi}

Olisi toivottavaa, että musiikintutkimuksen kaksi pääsuuntausta, etnomusikologia ja länsimaisen taidemusiikin tutkimus, kykenisivät uudistumaan ja laajentamaan näkökulmiaan. Etnomusikologialta voi toivoa historiallisen ulottuvuuden syventämistä. Länsimaisen taidemusiikin tutkimuksen soisi puolestaan ottavan etäisyyttä partituureihin ja kiinnostuvan myös esityskäytännöstä. Levytetty musiikki on näiden uusien linjanmäärittelyiden yhteinen tekijä, joka antaa tutkimukselle sekä historiallisen että esityskäytännöllisen ulottuvuuden. Tällainen musiikintutkimus ylittäisi aiempaa helpommin keinotekoisen jaon länsimaiseen taidemusiikkiin keskittyvän musiikkitieteen ja kaikkea muuta tutkivan etnomusikologian väliltä.

Ensimmäinen askel etnomusikologian uudistumisen suuntaa on lähdekriittisten menetelmien ja niiden käyttörutiinin kehittäminen. Tässä artikkelissa käsiteltyjen sovellusten lisäksi voisi pohtia myös esimerkiksi äänitteen joskus monimutkaisiin tekijäongelmiin liittyvää lähdekritiikkiä. Aivan toisenlainen, hyvin laaja ongelmavyyhti liittyy elokuvien ja muun filmimateriaalin käyttöön musiikintutkimuksessa. Tämäkin lähderyhmä on paljolti tutkijoiden unohtama.

\section{Kiitokset}

Haluan kiittää Pekka Gronowia, Marko Joustetta, Vesa Kurkelaa ja Simo Westerholmia, jotka ovat antaneet arvokasta apua tämän artikkelin eri kehitysvaiheissa.

\section{Lähteet}

\section{Kirjallisuus}

Ayangil, Ruhi 1994. Kanto. Istanbul Ansiklopedisi cilt 4, toim. Dünden Bugüne. İstanbul: Kültür bakanliğı ve tahir vakfı'nın ortak yayınıdır.

Berlin, Edward A. 1980. Ragtime. Musical and Cultural History. Berkeley Los Angeles - London: University of California Press. 
Blum, Stephen 1993. Prologue. Ethnomusicology and Modern Music History, toim. Stephen Blum et al., 1-20. Urbana - Chicago: University of Illinois Press.

Borwick, John 1995. 70 Years of Electrical Recording. Gramophone. November 1995, 208.

Conte, Pat 1995. The Fourth World: From Stone Age to New Age. CD-levyn The Secret Museum of Mankind (Yazoo 7004) oheisvihko.

Dahl, Ottar 1970. Historiantutkimuksen metodiopin peruspiirteitä. Helsinki: Weilin + Göös.

Delaunay, Charles 1961. Django Reinhardt. London: Cassell.

Frith, Simon 1988. Music for Pleasure. Essays in the Sociology of Pop. Cambridge: Polity Press.

Gronow, Pekka 1981. The Record Industry comes to the Orient. Ethnomusico$\log y 25: 2,251-284$.

Gronow, Pekka 1982. Ethnic Recordings: An Introduction. Ethnic Recordings in America. A Neglected Heritage, 1-49. Studies in American Folklife, No. 1. Washington DC: Library of Congress.

Gronow, Pekka 1983. The record industry: the growth of a mass medium. Popular Music 3. Producers and Markets, toim. Richard Middleton et al., 53-75. Cambridge: Cambridge University Press.

Gronow, Pekka 1991. Äänilevy tutkimuksen lähteenä ja kohteena. Kansanmusiikin tutkimus. Metodologian opas, toim. Pirkko Moisala, 227-239. Helsinki: VAPK-kustannus.

Gronow, Pekka ja Ilpo Saunio 1970. Äänilevytieto. Levyhyllyn käsikirja. Porvoo ja Helsinki: WSOY.

Gronow, Pekka ja Ilpo Saunio 1990. Äänilevyn historia. Porvoo - Helsinki Juva: WSOY.

Karttunen, Antero 1995. Oikea, uusi ja väärä Andante festivo. Classica 1995:3, 4-5.

Kurkela, Vesa 1991. Etnomusikologian historiattomuus ja nykyajan haasteet. Kansanmusiikin tutkimus. Metodologian opas, toim. Pirkko Moisala, 86-101. Helsinki: VAPK-kustannus.

Lilliestam, Lars 1988. Musikalisk ackulturation - från blues till rock. En studie kring låten Hound Dog. Skrifter från Musikvetenskapliga institutionen i Göteborg: 20. Göteborg: Musikvetenskapliga institutionen.

Muikku, Jari 1994. Äänite ja musiikki. Ä̈nitteen, musiikin ja ääniteteollisuuden välisistä vuorovaikutussuhteista. Tutkielma filosofian lisensiaatin tutkintoa varten. Helsingin yliopisto, Musiikkitieteen laitos. Joulukuu 1994.

Pennanen, Risto Pekka 1995. A Recent Reissue of Rebetika Recordings; Arhio Ellinikis diskografias. Asian Music 26:2, 137-142.

Racy, Ali Jihad 1976. Record Industry and Egyptian Traditional Music: 1904-1932. Ethnomusicology 20:1, 23-48. 
Racy, Ali Jihad 1988. Sound and Society: The Takht Music of Early-Twentieth Century Cairo. Selected Reports in Ethnomusicology. Volume VII. Issues in the Conceptualization of Music, 139-170. Los Angeles: University of California. Rice, Timothy 1987. Toward the Remodelling of Ethnomusicology. Ethnomusicology 31:3, 469-488.

Rust, Brian 1980. Brian Rust's Guide to Discography. Discographies, Number 4. Westport - London: Greenwood Press.

Sapoznik Henry 1987. The Compleat Klezmer. Cedarhurst: Tara.

Sapoznik, Henry 1991. Dave Tarras: Father of Yiddish-American Klezmer Music. CD-levyn Dave Tarras, Yiddish-American Klezmer Music 1925-1956 (Yazoo 7001) oheisvihko.

Shelemay, Kay Kaufman 1987. Response to Rice. Ethnomusicology 31:3, 489-490.

Sitsky, Larry 1986. Busoni and the Piano. The Works, the Writings, and the Recordings. Contributions to the Study of Music and Dance, Number 7. New York - Westport - London: Greenwood Press.

Slobin, Mark 1984. Peasant Music Cultures of Eastern Europe. Worlds of Music. An Introduction to the Music of the World's Peoples, toim. Jeff Todd Titon, 166-207. New York: Schrimrer Books.

Smith, Ole. L. 1989. Research on Rebetika: Some Methodological Problems and Issues. Journal of Modern Hellenism No. 6, 177-190.

Smith, Ole. L. 1991. The chronology of Rebetiko - a reconsideration of the evidence. Byzantine and Modern Greek Studies 15, 318-324.

Soffa, David 1994. CD-levyn Marika Papagika, Greek Popular and Rebetic Music in New York 1918-1929 (Alma Criolla ACCD 802) oheisvihko.

Spotswood, Richard 1990. Ethnic Music on Record. A Discography of Ethnic Recordings made in the United States, 1893-1942 Vol. 1-6. Urbana and Chicago: University of Illinois Press.

Spotswood, Richard 1993. Pawlo Humeniuk. CD-levyn Pawlo Humeniuk, King of the Ukrainian Fiddlers. New York 1925-1927. The Early Years. (Arhoolie Folklyric CD 7025) oheisvihko.

Strötbaum, Hugo 1992. Seventy-Eight Revolutions per Minute in the Levant. Discography of Favourite's Oriental Recordings. De Turcicis Aliisque Rebus Commentarii Henry Hofman dedicati. Utrecht Turcological Series Vol. 2, 149-189. Utrecht: Instituut voor Oosterse Talen en Culturen.

Tawaststjerna, Erik 1988. Jean Sibelius 5. Helsinki: Otava.

Wolfson, John 1987. Alessandro Moreschi. CD-levyn Alessandro Moreschi - The Last Castrato. Complete Vatican Recordings. (Pearl Opal CD 9823) oheisvihko. Wuori, Timo 1994. Vastine Aksentissa 10/93 olleeseen levyarvosteluun Malmstén, Eugen \& Rytmi-Pojat: Unohtumattomat. Aksentti 1994:1, 64. 


\section{Haastattelut}

Gronow, Pekka. Puhelinhaastattelu 6.11.1995.

Westerholm, Simo. Puhelinhaastattelu 12.11.1995.

Äänilevyt

Arhoolie CD 7025. Pawlo Humeniuk, King of the Ukrainian Fiddlers. New York 1925-1927. The Early Years, toim. Dick Spotswood. El Cerrito 1993. CBS 53753. Ta prota rebetika. Istorikes ihografisis 1900-1913, toim. Tasos Shorelis. Athina 1976.

EMI Regal 14C 034-70364. Rebetiki istoria 1925-55, toim. Kostas Hadzidulis. Athina 1975.

KICD 34. Finnish-American Recordings 3. Ernest Paananen, Naimahommia, toim. Simo Westerholm. Kansanmusiikki-instituutti. Kaustinen 1995.

Minos-EMI 72434804102 9. Roza Eskenazi I. Arhio ellinikis diskografias: tragudistes tu rebetiku, toim. Panajotis Kunadis. Athina 1994.

Ocora C 560081. Turquie, Archives de la musique turquie I, toim. Christian Poché \& Bernard Moussali. Paris 1995.

Orfeon 11614. Protopsaltis J. Nafpliotis. Erhomenos o Kirios. Istanbul n. 1912.

Pearl GEMM CD 9101. Great Virtuosi of the Golden Age, Volume I: Ysaye, Sarasate, Joachim, Elman, Powell, toim. George Singer. Sparrows Green 1988.

Pearl GEMM CD 9102. Great Virtuosi of the Golden Age, Volume II: Kubelik, Kreisler, Thibaud, Hall, Drdla, von Vecsey, toim. George Singer. Sparrows Green 1988.

Pearl Opal CD 9823. Alessandro Moreschi - The Last Castrato. Complete Vatican Recordings, toim. John Wolfson. Sparrows Green 1987.

Radio Suomi CDY 163. Ratto, huove ja luote: radion ajanvietemusiikin aarteita 1935-1959, toim. Juhani Similä et al. Helsinki 1994.

Scandia SLP-567. Historiallista Sibeliusta III. Helsinki 1972.

Sound Cat MILP-197. Eugen Malmstén ja Rytmi-Pojat 1935-1937, toim. Harry Aaltonen. 1988.

Sound Cat MICD-197/198. Eugen Malmstén ja Rytmi-Pojat, Unohtumattomat, toim. Timo Wuori. 1993.

Traditional Crossroads CD 4266. Istanbul 1925, Classic Recordings from the Middle East made from the Original Metal Parts, toim. Harold G. Agopian. New York 1994. 